\title{
Protein and amino acid content in compatible and incompatible peach/plum grafts
}

\author{
By M. A. MORENO, ${ }^{1,2}$ J. P. GAUDILLERE ${ }^{3}$ and A. MOING \\ 'INRA, Centre de Bordeaux, Station de Recherches Fruitières, BP 81, 33883 Villenave d'Ornon \\ Cedex, France \\ ${ }^{2}$ Present address: CSIC, Estación Experimental de Aula Dei, Departamento de Pomología, \\ Apartado 202, 50080 Zaragoza, Spain \\ ${ }^{3}$ INRA, Centre de Bordeaux, Station de Physiologie Végétale, BP 81, 33883 Villenave d'Ornon \\ Cedex, France
}

\begin{abstract}
SUMMARY
Amino acid and soluble protein contents were studied in one compatible peach/plum graft (Prunus persica cv. Springtime/Prunus cerasifera cv. myrobalan P 2032) and one incompatible graft (Prunus persica cv. Springtime/Prunus cerasifera cv. myrobalan P 18) for three months after grafting. During a first period, between Days 57 and 78 after grafting, soluble proteins and free amino acids per tree were remobilized from the rootstock in both graft combinations. During a second period, between Days 78 and 89 , soluble protein content per tree remained constant in the rootstock of both graft combinations, whereas total free amino acids per tree continued to decrease in the rootstock of the incompatible graft combination and stabilized in the compatible one. In the peach scion and the myrobalan rootstock, asparagine, aspartate, glutamate and arginine were the major free amino acids. Their concentration in the roots was unaffected or only little influenced by incompatibility. Free amino acid and soluble protein concentration in the incompatible rootstock was not indicative of nitrogen starvation or of carbohydrate starvation. In peach scions, at the end of the experiment, the soluble protein concentration was lower in all the organs in the incompatible grafts. The same pattern was found in scion for asparagine, aspartate and glutamate concentrations. This is indicative of nitrogen starvation in the aerial parts.
\end{abstract}

THE internal cycling of nitrogenous reserves is an important feature for growth of temperate fruit trees (Titus and Kang, 1982). Nitrogen absorption and assimilation interact with carbon assimilation and partitioning, which can be modified by environmental factors, by genetic control (Poorter et al., 1990) or by grafting.

When peach (Prunus persica L. Batsch) is grafted on myrobalan plum (Prunus cerasifera L. Ehrh) the source-sink relationships depend on the genotype of the rootstock. Most peach/ myrobalan graft combinations rapidly develop the typical symptoms of "translocated" graft incompatibility as defined by Herrero (1951) and Mosse (1962). However, the mechanism underlying graft incompatibility remains poorly understood. Tabuenca (1962) and Breen (1975) suggested impaired phloem transport from the aerial parts to the roots. However,
Moing and Carde (1988) and Moing and Gaudillère (1992) showed that transport of carbohydrates, although slowed down, was not blocked at the graft union. Moing et al., (1990) reported that growth of the scion of an incompatible graft combination was not limited by water or carbon supply, but may be limited by nitrogen supply as suggested by Breen and Muraoka (1975).

In previous work, using ${ }^{15} \mathrm{NO}_{3}$ labelling, Moing and Gaudillère (1992) estimated the contribution of the total nitrogen reserves of the rootstock to scion growth. They showed that, although total nitrogen concentration in the rootstock organs of the incompatible graft was never significantly lower than in the compatible one, nitrogen absorption and assimilation in the incompatible graft ceased 11 weeks after grafting whereas it continued in the com- 
patible graft. However, the biochemical forms of nitrogen reserves were not studied.

The aim of the present work was to look for an early biochemical marker of carbon and/or nitrogen starvation at the rootstock level, and nitrogen starvation at the scion level, in the incompatible grafts, by studying the level and biochemical forms of nitrogen reserves. Free amino acids and soluble proteins, representing forms of nitrogen reserves, were analyzed in the different organs of compatible and incompatible peach/myrobalan graft combinations.

\section{MATERIALS AND METHODS \\ Plant culture and sampling}

Hardwood cuttings of P 18 and P 2032, two clones of myrobalan (Prunus cerasifera), were rooted in the nursery during the winter. In the following autumn, the rooted cuttings were potted and transferred to a greenhouse where they were T-budded with peach cv. Springtime (Prunus persica). Clone $\mathrm{P} 18$, from myrobalan $\mathrm{B}$, is incompatible with all peach varieties while clone P 2032 seems compatible with most peach varieties (Graselly, 1983). Clone $P 18$ and $P$ 2032 are incompatible and compatible, respectively, with peach cv. Springtime. At scion bud burst, on Day 57 ( 57 days after grafting), three plants of each graft combination were collected for initial analysis, and six other plants of each graft combination were placed in a growth chamber providing a $13 \mathrm{~h}$ photoperiod, a day/ night temperature of $25 / 20^{\circ} \mathrm{C}$, a $\mathrm{CO}_{2}$ concentration of about $370 \mu \mathrm{I} \mathrm{I}^{-1}$ and a nutrient solution for fertilization (Moing and Gaudillère, 1992). The nitrogen source was nitrate. On two dates (Day 78 and Day 89), three plants of each graft combination were harvested.

The plants from the three sampling dates (Day 57, Day 78 and Day 89) were divided into individual organs (apex, adult leaves, shoot of the scion, stem of the rootstock, roots $>4 \mathrm{~mm}$ in diameter, roots $<4 \mathrm{~mm}$ in diameter) and freezedried. The dried material was then ground to a fine powder ( 20 mesh) in a laboratory mill.

\section{Amount of nitrogen}

Total nitrogen was calculated from data of dry weight and nitrogen concentration reported previously (Moing and Gaudillère, 1992).

\section{Amino acid analysis}

The dried powders were extracted twice for amino acids with hot ethanol/water ( $80 / 20$ and $50 / 50, \mathrm{v} / \mathrm{v})$. The supernatants were purified on an ion-exchange resin (Dowex 50W in the $\mathrm{H}^{+}$ form) using 1.4 $\mathrm{N} \mathrm{NH}_{4} \mathrm{OH}$ as eluant.

Amino acids were analyzed by reversedphase HPLC using the o-phthaldialdehydethiol method described by Joseph and Marsden (1986). The gradient mixture used for HPLC and the amino acid elution has been described by Brouquisse et al. (1992). Calibration used a solution of amino acid standards from Sigma Chemical Company (St. Louis, USA). Total amino acids refers to the sum of alanine, $\gamma$-aminobutyric acid, arginine, asparagine, aspartate, glycine, glutamate, glutamine, histidine, isoleucine, methionine, leucine, lysine, phenylalanine, serine, threonine, tryptophan and valine.

The results, averaged from determinations from three replicate plants, were expressed as $\mu \mathrm{g}$ or $\mathrm{mg}$ nitrogen equivalent.

\section{Extraction and determination of soluble proteins}

The dried powders were extracted over ice in $100 \mathrm{mM}$ Tris-(hydroxymethyl)aminomethane buffer $(\mathrm{pH}=7.5)$, containing ascorbic acid $3 \%$ (w/v), $5 \mathrm{mM}$ dithiothreitol, glycerol $10 \%$ (v/v), and $50 \mu \mathrm{M}$ chymostatin, $2 \mathrm{mM}$ phenylmethylsulphonyl fluoride and $100 \mu \mathrm{M}$ leupeptin, as antiproteases. The extraction buffer was added after mixing the dried powders with insoluble Polyvinylpyrrolidone and Amberlite XAD-2 (Sigma), using a 2:1 and 1:1 (w:w) ratio of compound to tissue, respectively.

The homogenate was filtered rapidly through glass wool and centrifuged at $6000 \mathrm{~g}$ for $10 \mathrm{~min}$, at $4^{\circ} \mathrm{C}$. The supernatant obtained is referred to as the water-soluble protein extract.

An aliquot of this protein crude extract was used for protein determination according to the method described by Bradford (1976) using the Bio-Rad (Richmond, VA) protein assay with $\gamma$-globulin from Calbiochem Co. (La Jolla, CA USA) as standard.

\section{Analysis of data}

The results were expressed as concentration ( $\mu \mathrm{g}$ or mg nitrogen or $\gamma$-globulin equivalent per g dry weight tissue), or as total amount of nitrogen equivalent $\left(\mathrm{mg}\right.$ tre $\mathrm{e}^{-1}$ ) calculated as the sum of concentration $\times$ dry weight of all organs in the scion and rootstock of graft combinations. 

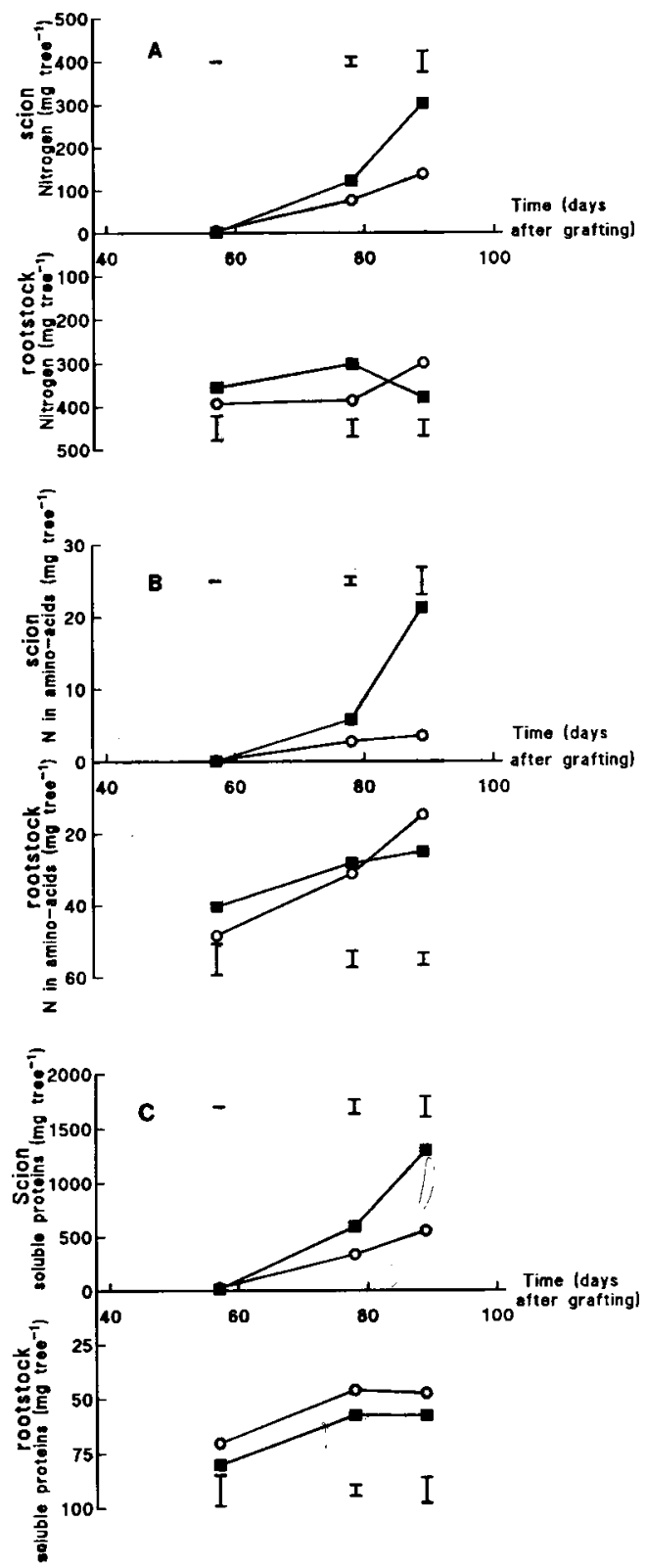

FiG. 1

Changes over time in the total content of nitrogen or nitrogenous compounds in the peach scion and the myrobalan rootstock in compatible and incompatible grafts. Vertical bar represents standard error of difference ( 4 d.f.). Filled square $=$ Springtime/P 2032 (compatible graft); open circle $=$ Springtime $/ P 18$ (incompatible graft). A: total nitrogen content after Kjeldahl digestion (calculated from the data of Moing and Gaudillère, 1992). B: total content of nitrogen in amino acids ( $\mathrm{mg} \mathrm{N}$ per tree). C: content of soluble proteins ( $\mathrm{mg} \gamma$ globulin equivalent per tree).

Statistical differences between means were determined by the Student $t$-test.

\section{RESULTS}

Amount of nitrogen, free amino acids and soluble proteins per tree

On Days 57 and 78, the total amount of nitrogen, the amount of nitrogen in the sum of free amino acids, and the total amount of soluble proteins per tree were not significantly different in the two graft combinations, either in the rootstock or in the scion (Figure 1).

Between Days 78 and 89 , the amount of nitrogen in the sum of free amino acids in the rootstock (Figure 1B) decreased significantly in the incompatible grafts while it remained constant in the compatible ones, and it was significantly higher in the compatible grafts than in the incompatible ones on Day 89.

In the scion, from Day 78 to Day 89 , all variables (Figure 1) increased significantly in the compatible grafts but remained constant in the incompatible ones. The values were significantly higher in compatible grafts than in incompatible ones on Day 89.

\section{Total free amino acid concentration}

In rootstock stem, the total free amino acid

TABLE I

Total amino acid concentration, expressed as nitrogen equivalent $\left(\mu \mathrm{gN} \mathrm{gDW} W^{-t}\right)$, in the different organs of compatible (Spr./P 2032) and incompatible (Spr./P 18) graft combinations for three sampling dates

\begin{tabular}{lcccc}
\hline Organ & $\begin{array}{c}\text { Days after } \\
\text { grafting }\end{array}$ & $\begin{array}{c}\text { Spr./ } \\
\text { P 2032 }\end{array}$ & $\begin{array}{r}\text { Spr./ } \\
\text { P 18 }\end{array}$ & $\begin{array}{c}\text { SED } \\
\text { (4 d.f.) }\end{array}$ \\
\hline Apex & 57 & 1890 & 893 & 587 \\
& 78 & 4017 & 2013 & 988 \\
Adult leaves & 89 & 4980 & $823^{*}$ & 476 \\
& 78 & 1550 & 955 & 807 \\
Scion bark & 89 & 2418 & $560^{*}$ & 444 \\
& 78 & 1497 & $2975^{*}$ & 345 \\
Scion wood & 89 & 3013 & $918^{*}$ & 194 \\
& 78 & 850 & $1673^{*}$ & 113 \\
Rootstock stem & 89 & 2194 & $1159^{*}$ & 210 \\
& 57 & 385 & 598 & 99 \\
Rootstock roots & 78 & 146 & 182 & 57 \\
$>4$ mm & 89 & 31 & 42 & 10 \\
& 78 & 1807 & 1744 & 267 \\
Rootstock roots & 89 & 1316 & 1765 & 177 \\
$<4$ mm & 57 & 1302 & 1750 & 252 \\
& 78 & 962 & 834 & 102 \\
& 89 & 602 & 447 & 70 \\
\hline
\end{tabular}

For each sampling date and for each organ, an asterisk indicates a statistically significant difference between the two combinations $\quad(P<0.05) . \quad$ SED $=$ Standard error of difference. 
TABLE II

Asparagine, glutamate, aspartate and arginine concentration $\left(\mu \mathrm{gN} g D W^{-1}\right)$ in the rootstock organs of compatible (Spr./P 2032) and incompatible (Spr. /P 18) graft combinations for three sampling dates

\begin{tabular}{|c|c|c|c|c|}
\hline Organ & $\begin{array}{c}\text { Days after } \\
\text { grafting }\end{array}$ & $\begin{array}{c}\text { Spr./ } \\
\text { P } 2032\end{array}$ & $\begin{array}{l}\text { Spr./ } \\
\text { P } 18\end{array}$ & $\begin{array}{c}\text { SED } \\
\text { (4 d.f.) }\end{array}$ \\
\hline Asparagine & & & & \\
\hline Stem & $\begin{array}{l}57 \\
78 \\
89\end{array}$ & $\begin{array}{r}67 \\
42 \\
3\end{array}$ & $\begin{array}{r}87 \\
39 \\
6\end{array}$ & $\begin{array}{r}15 \\
22 \\
2\end{array}$ \\
\hline Roots $>4 \mathrm{~mm}$ & $\begin{array}{l}57 \\
78 \\
89\end{array}$ & $\begin{array}{l}767 \\
624 \\
582\end{array}$ & $\begin{array}{l}860 \\
798 \\
834\end{array}$ & $\begin{array}{r}81 \\
127 \\
98\end{array}$ \\
\hline Roots $<4 \mathrm{~mm}$ & $\begin{array}{l}57 \\
78 \\
89\end{array}$ & $\begin{array}{l}585 \\
487 \\
328\end{array}$ & $\begin{array}{l}722 \\
451 \\
213^{*}\end{array}$ & $\begin{array}{r}145 \\
80 \\
40\end{array}$ \\
\hline Glutamate & & & & \\
\hline Stem & $\begin{array}{l}57 \\
78 \\
89\end{array}$ & $\begin{array}{r}13 \\
8 \\
3\end{array}$ & $\begin{array}{r}10 \\
8 \\
1\end{array}$ & $\begin{array}{l}2 \\
3 \\
1\end{array}$ \\
\hline Roots $>4 \mathrm{~mm}$ & $\begin{array}{l}57 \\
78 \\
89\end{array}$ & $\begin{array}{l}69 \\
57 \\
69\end{array}$ & $\begin{array}{l}43 \\
50 \\
59 *\end{array}$ & $\begin{array}{r}15 \\
4 \\
2\end{array}$ \\
\hline Roots $<4 \mathrm{~mm}$ & $\begin{array}{l}57 \\
78 \\
89\end{array}$ & $\begin{array}{l}39 \\
48 \\
38\end{array}$ & $\begin{array}{l}31 \\
38 * \\
28\end{array}$ & $\begin{array}{l}5 \\
2 \\
8\end{array}$ \\
\hline Aspartate & & & & \\
\hline Stem & $\begin{array}{l}57 \\
78 \\
89\end{array}$ & $\begin{array}{r}14 \\
13 \\
1\end{array}$ & $\begin{array}{r}21 \\
14 \\
4\end{array}$ & $\begin{array}{l}4 \\
5 \\
2\end{array}$ \\
\hline Roots $>4 \mathrm{~mm}$ & $\begin{array}{l}57 \\
78 \\
89\end{array}$ & $\begin{array}{l}42 \\
43 \\
57\end{array}$ & $\begin{array}{l}45 \\
56^{*} \\
50\end{array}$ & $\begin{array}{l}4 \\
4 \\
8\end{array}$ \\
\hline Roots $<4 \mathrm{~mm}$ & $\begin{array}{l}57 \\
78 \\
89\end{array}$ & $\begin{array}{l}31 \\
36 \\
24\end{array}$ & $\begin{array}{l}28 \\
31 \\
20\end{array}$ & $\begin{array}{l}3 \\
5 \\
5\end{array}$ \\
\hline Arginine & & & & \\
\hline Stem & $\begin{array}{l}57 \\
78 \\
89\end{array}$ & $\begin{array}{r}252 \\
50 \\
6\end{array}$ & $\begin{array}{r}426 \\
95 \\
17\end{array}$ & $\begin{array}{r}83 \\
31 \\
6\end{array}$ \\
\hline Roots $>4 \mathrm{~mm}$ & $\begin{array}{l}57 \\
78 \\
89\end{array}$ & $\begin{array}{l}851 \\
476 \\
510\end{array}$ & $\begin{array}{l}706 \\
734 \\
694\end{array}$ & $\begin{array}{l}189 \\
120 \\
192\end{array}$ \\
\hline Roots $<4 \mathrm{~mm}$ & $\begin{array}{l}57 \\
78 \\
89\end{array}$ & $\begin{array}{l}493 \\
308 \\
157\end{array}$ & $\begin{array}{l}263 \\
258 \\
140\end{array}$ & $\begin{array}{l}92 \\
37 \\
41\end{array}$ \\
\hline
\end{tabular}

For each sampling date and for each organ, an asterisk indicates a statistically significant difference between the two combinations $(P<0.05)$. SED $=$ Standard error of difference.

concentration (Table I) decreased significantly in both graft combinations between Days 57 and 78, and in incompatible graft between Days 78 and 89 . For both graft combinations, the stem total free amino acid concentration on Day 89 was about $7.5 \%$ of that on Day 57 . In the roots $<4 \mathrm{~mm}$ of both graft combinations the concentration decreased significantly between Days 78 and 89 , whereas it was constant in roots $>4 \mathrm{~mm}$. Total free amino acid concentration in the rootstock stem and roots did not differ sig- nificantly between the incompatible graft and the compatible one.

In the scion, the total free amino acid concentration (Table I) was higher in the bark and in the wood of incompatible grafts than in those of the compatible ones on Day 78. It decreased significantly in the bark of the incompatible grafts between Days 78 and 89 , in contrast to the compatible ones where it increased. On Day 89 , the total free amino acid concentration in all the organs of the scion was significantly lower in the incompatible graft compared to the

TABLE III

Asparagine, glutamate, aspartate and arginine concentration ( $\mu \mathrm{gNgDW^{-1 }}$ ) in the scion organs of compatible (Spr./P 2032) and incompatible (Spr. /P 18) graft combinations for three sampling dates

\begin{tabular}{lllll}
\hline & $\begin{array}{c}\text { Days after } \\
\text { grafting }\end{array}$ & Spr./ & Spr./ & SED \\
Organ & Pran2 & P 18 & (4 d.f.) \\
\hline
\end{tabular}

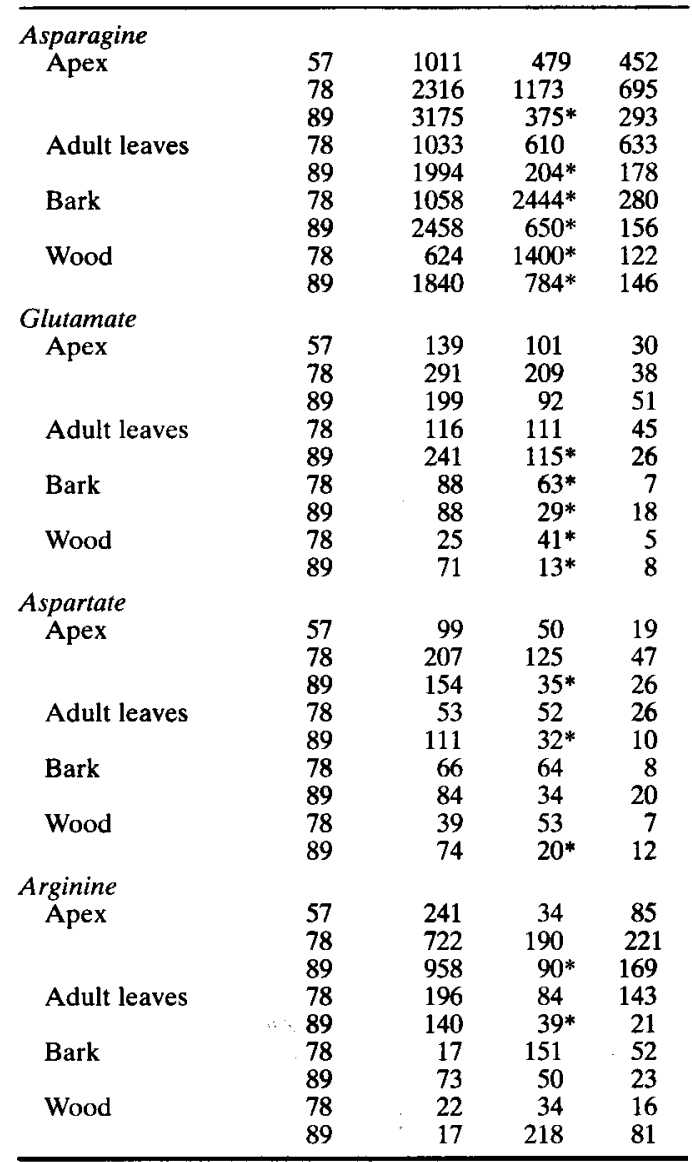

For each sampling date and for each organ, an asterisk indicates a statistically significant difference between the two combinations $(P<0.05)$. SED = Standard error of difference. 
TABLE IV

Soluble protein concentration (mg $\gamma$ globulin equivalent $\mathrm{g} D \mathrm{~W}^{-l}$ ), in the different organs of compatible (Spr./P 2032) and incompatible (Spr./P 18) graft combinations for three sampling dătes

\begin{tabular}{lcccc}
\hline Organ & $\begin{array}{c}\text { Days after } \\
\text { grafting }\end{array}$ & $\begin{array}{c}\text { Spr./ } \\
\text { P 2032 }\end{array}$ & $\begin{array}{c}\text { Spr./ } \\
\text { P 18 }\end{array}$ & $\begin{array}{c}\text { SED } \\
(4 \text { d.f. })\end{array}$ \\
\hline Apex & 78 & 217.1 & 135.9 & 37.5 \\
& 89 & 153.8 & $51.8^{*}$ & 22.9 \\
Adult leaves & 78 & 244.0 & 199.1 & 42.3 \\
& 89 & 257.3 & $133.2^{*}$ & 21.4 \\
Scion bark & 78 & 56.8 & $19.5^{*}$ & 11.2 \\
& 89 & 64.9 & $2.3^{*}$ & 8.6 \\
Scion wood & 78 & 23.1 & 22.2 & 1.5 \\
& 89 & 21.0 & $9.8^{*}$ & 2.2 \\
Rootstock stem & 57 & 1.4 & 1.3 & 0.4 \\
& 78 & 0.9 & 0.9 & 0.3 \\
Rootstock roots & 89 & 0.5 & 1.0 & 0.3 \\
$>4$ mm & 57 & 2.6 & $1.2^{*}$ & 0.3 \\
& 78 & 1.8 & $0.9^{*}$ & 0.2 \\
Rootstock roots & 89 & 1.9 & 2.1 & 0.6 \\
<4 mm & 57 & 1.6 & 1.5 & 0.2 \\
& 78 & 1.2 & 1.0 & 0.3 \\
& 89 & 1.3 & 1.1 & 0.3 \\
\hline
\end{tabular}

For each sampling date and for each organ, an asterisk indicates a statistically significant difference between the two combinations $\quad(P<0.05) . \quad$ SED $=$ Standard error of difference.

compatible one, even in those where this concentration was higher in the incompatible graft than in the compatible one on Day 78.

Asparagine, arginine, glutamate and aspartate were the predominant free amino acids in the rootstock (Table II). Asparagine was the major amino acid recovered in the roots, representing up to $50 \%$ (mol asparagine per mol amino acids) and arginine predominated in the rootstock stem, representing up to $25 \%$ (mol arginine per mol amino acids). Asparagine, glutamate and aspartate were the predominant free amino acids in all the organs of the scion (Table III). Asparagine was the most abundant, representing up to $70 \%$ (mol asparagine per mol amino acids) of total free amino acid concentration in both wood and bark.

\section{Asparagine, glutamate, aspartate and arginine concentration in the rootstock}

Between Days 57 and 89, asparagine concentration (expressed as $\mathrm{N}$ equivalent, Table II) decreased significantly in the rootstock stem of both graft combinations, in the roots $>4 \mathrm{~mm}$ of the compatible grafts and in the roots $<4 \mathrm{~mm}$ of the incompatible grafts, where it was signifcantly lower on Day 89 than in the compatible ones. Glutamate concentration (Table II) decreased with time only in the rootstock stem and in roots $<4 \mathrm{~mm}$ of the incompatible grafts between Days 78 and 89 . It was lower in roots $<4 \mathrm{~mm}$ on Day 78 and roots $>4 \mathrm{~mm}$ on Day 89 , in the incompatible grafts in comparison with the compatible ones. Aspartate concentration (Table II) increased significantly in roots $>4 \mathrm{~mm}$ of the incompatible graft between Days 57 and 78 , being significantly higher in the incompatible grafts on Day 78 , but not on Day 89. Between Days 78 and 89 , it decreased significantly in the roots $<4 \mathrm{~mm}$ of the incompatible grafts and in the rootstock stem of the compatible ones. Arginine concentration (Table II) decreased significantly in the rootstock stem of both graft combinations between Days 57 and 78, as with the same organ and roots $<4 \mathrm{~mm}$ between Days 78 and 89 .

\section{Asparagine, glutamate, aspartate and arginine concentration in the scion}

Between Days 57 and 89, asparagine concentration (Table III) increased significantly in the apex of the compatible grafts but remained constant in the incompatible ones. On Day 78, it was higher in the bark and the wood of the incompatible graft compared with the compatible one. However, between Days 78 and 89, it decreased significantly in the bark and the wood of the incompatible graft while it increased in those of the compatible one. On Day 89, asparagine concentration was lower in all the scion organs of the incompatible graft than in the equivalent ones of the compatible one, this difference being especially significant $(P<0.001)$ in the apex and adult leaves. Glutamate concentration (Table III) decreased significantly in the bark and the wood of the incompatible graft, whilst it increased or remained stable in the compatible one between Days 78 and 89 . It was lower in the adult leaves, the bark and the wood of the incompatible graft on Day 89. This difference was already noticeable on Day 78 for the bark. Aspartate concentration (Table III) decreased significantly in the wood of the incompatible grafts whereas it increased in the compatible ones. It was lower in the apex, the adult leaves and the wood of the incompatible grafts compared to the compatible ones on Day 89. Arginine concentration (Table III) was constant in all the organs except in the bark of compatible grafts where it increased between Days 78 and 89 . On Day 89 , 
it was lower in the apex and adult leaves of the incompatible graft than of the compatible one.

\section{Soluble protein concentration}

In the rootstock, the soluble protein concentration (Table IV) was significantly lower in rootstock roots $>4 \mathrm{~mm}$ of the incompatible grafts than in those of the compatible ones on Days 57 and 78. However, this difference was neither significant on Day 89 for roots $>4 \mathrm{~mm}$, nor on all dates for roots $<4 \mathrm{~mm}$ and rootstock stem.

In the scion, the soluble protein concentration (Table IV) remained constant in the compatible grafts and decreased significantly in the wood and the apex of the incompatible ones. The soluble protein concentration was significantly lower in all the scion organs of the incompatible graft compared with the compatible one on Day 89 (Table IV). This difference was already significant for the bark on Day 78 and concentration dropped to a value 30 times less than that in the compatible graft on Day 89.

\section{DISCUSSION \\ Mobilization of stored nitrogen}

During the first period, nitrogen reserves were strongly mobilized from the rootstock roots and stem in both graft combinations. This is in accordance with reutilization of stored nitrogen during spring growth which has been well established in trees (Taylor and May, 1967; O'Kennedy and Titus, 1979; Stassen et al., 1981; Wetzel et al., 1989; Arora et al., 1992). Mobilization was particularly great in the rootstock stem while in the roots it seemed restricted to arginine and asparagine. The role of free arginine, or arginine-rich proteins, as a storage form of nitrogen has been reported (Taylor and May, 1967; Hill-Cottingham and Lloyd-Jones, 1973; Tromp and Ovaa, 1973). In myrobalan, arginine was the major free amino acid in the stem and second in importance in the roots, where asparagine was predominant in accordance with Tromp and Ovaa (1976). Nevertheless, arginine mobilization was not affected by graft incompatibility.

A significant proportion of root free aminoacids and soluble proteins was not readily mobilized in the incompatible combination. Although no new nitrogen was assimilated during the second period (Moing and Gaudillère, 1992), the roots of incompatible grafts seemed not to be nitrogen starved at the end of the experiment.

\section{Scion nitrogen demand}

The total nitrogen demand in the scion in the incompatible graft was lower than in the compatible one. The total free amino acid and soluble protein concentration decreased in most organs of the scion in the incompatible graft while it increased or remained constant in the compatible one. This is in agreement with a decrease in the absorption and assimilation of nitrate in roots of the incompatible graft, since roots are classically regarded as the site of nitrate reduction in fruit trees (Lee and Titus, 1992).

At the end of the first period, asparagine concentration was twice as high in the bark and wood of the scion of the incompatible grafts as in the compatible ones. This accumulation may be a precocious indication of the decrease in scion growth rate (Moing and Gaudillère, 1992). During the second period, free amino acids and soluble protein concentration decreased in the incompatible graft, indicating that proteins recently stored in the mature tissues could be remobilized to supply nitrogen to the scion growing tissues. At the end of the present experiment, when no nitrogen was assimilated by the roots of the incompatible grafts, as shown using ${ }^{15} \mathrm{~N}$ labelling (Moing and Gaudillère, 1992), both the soluble proteins or/ and free amino acids in the bark and wood of scion seem to be remobilized to a greater extent. Millard and Neilsen (1989), working with nitrogen-deficient apple trees, reported that when no nitrogen was supplied, plants remobilized nitrogen from their stems to support leaf growth and later, when leaf growth stopped, remobilized some of the nitrogen from their leaves to support root growth. This second series of events could not occur in the case of graft incompatibility as phloem transfers from the aerial part to the roots were reduced (Moing and Gaudillère, 1992).

The nitrogen starvation symptoms observed in the aerial parts probably result from a blockage of nitrogen transfer from the roots to the scion, with nitrogen originating either from reserves or current assimilation.

\section{Rootstock-scion relationships}

In previous work, it was shown that nitrogen 
absorption and assimilation stopped when the rate of shoot growth of the incompatible graft declined, and that carbon export through the phloem slowed down as attested by the accumulation of non-structural carbohydrates in the scion (Moing and Gaudillère, 1992). However, the precise timing of these three events could not be determined.

One hypothesis is that nitrogen transfer from the roots to the scion may have been reduced (Breen and Muraoka, 1975), because absorption and assimilation of nitrate in roots stopped as carbohydrates were not available to supply energy and carbon skeletons (Titus and Kang, 1982). However, in the present study, the pattern of root amino acids and $\mathrm{NH}_{4}^{+}$(data not shown) in the incompatible graft was not indicative of degradative processes induced by carbohydrate starvation, as reported by Givan (1979) and Brouquisse et al. (1992).

Another possibility is that nitrogen transport itself, from the root to the shoot, was progressively blocked. The concentration of the major free amino-acids remained high in the main roots, and asparagine and arginine seemed to be readily available for xylem translocation, suggesting that the roots in the incompatible graft were functional. When the balance between carbohydrate import and utilization in the roots just begins to be disrupted, nitrogen sequestration in the root could be a consequence of a limitation of scion growth, to favour carbon partitioning to the rootstock. Nitrogen sequestration in the root could also directly limit scion growth. The measurement of enzymatic activities of nitrogen assimilation may help to verify this hypothesis in further studies.

\section{Conclusion}

The following series of physiological events are here proposed as markers of incompatibility at early stages. Initially, scion growth is sustained by the carbon and nitrogen stored in the rootstock. Later, the scion becomes autotrophic for carbon, but is still dependent for its nitrogen supply from the rootstock. However, the root carbohydrate supply from photosynthesis remains too low. We suggest that an early event is a response of the roots to this carbohydrate imbalance, as proposed in the model of shoot/root ratio regulation proposed by Farrar (1992). This response may be a signal to the aerial part asking for a stimulation of photosynthate allocation towards the roots. This signal would inhibit the growth of the shoot apex and consequently reduce the carbon and nitrogen demand of the shoot. Impaired phloem transport between scion and rootstock prevents the appropriate answer, i.e. a stimulated carbohydrate flux towards roots. This results in the collapse of all fluxes in the graft and in an overflow of carbohydrate in shoot, with a normal amount of transportable amino acids in roots.

The authors gratefully acknowledge Mrs. M. Gaudillère's help in the analysis of amino acids and Drs. R. Brouquisse and A. M. Casas, for helpful discussions. The study was partially supported by a Ministerio de Educación y Ciencia of Spain and Ministère de la Recherche et de la Technologie of France grant to first author.

\section{REFERENCES}

Arora, R., Wisniewski, M. E. and ScorzA, R. (1992). Cold acclimation in genetically related (sibling) deciduous and evergreen peach (Prunus persica L. Batsch). I. Seasonal changes in cold hardiness and polypeptides of bark and xylem tissues. Plant Physiology, 99, 1562-8.

BradFoRd, M. M. (1976). A rapid and sensitive method for the quantification of microgram quantities of proteins utilizing the principle of protein-dye binding. Analytical Biochemistry, 72, 248-54.

BREEN, P. J. (1975). Effect of peach/plum incompatibility on seasonal carbohydrate changes. Journal of the American Society for Horticultural Science, 100, 253-9.

BreEN, P. J. and MURAOKA, T. (1975). Seasonal nutrient levels and peach/plum graft incompatibility. Journal of the American Society for Horticultural Science, 100, 339-42.

Brouquisse, R., James, F., Pradet, A. and Raymond, P. (1992). Asparagine metabolism and nitrogen distribution during protein degradation in sugar-starved maize root tips. Planta, 188, 384-95. 
Farrar, J. F. (1992). The whole plant: carbon partitioning during development. In: Carbon partitioning within and between organisms. (Pollock, C., Farrar, J. and Gordon, T., Eds). BIOS Scientific Publishers Ltd, Oxford, 163-79.

Givan, C. V. (1979). Metabolic detoxification of ammonia in tissues of higher plants. Phytochemistry, 18, 375-82.

Grasselly, C. (1983). Possibilités d'utilisation du prunier myrobolan comme porte-greffe du pêcher. Comptes Rendus de l'Académie d'Agriculture de France, 69, 347-54.

Herrero, J. (1951). Studies of compatible and incompatible graft combinations with special reference to hardy fruit trees. Journal of Horticultural Science, 26, 186-237.

Hill-Cottingham, D. G. and Lloyd-Jones, C. P. (1973). Seasonal variations in absorption and metabolism of carbon ${ }^{-14}$ labelled arginine in intact apple stem tissue. Physiologia Plantarum, 29, 39-44.

Joseph, M. H. and Marsden, C. A. (1986). Aminoacids and small peptides. In: HPLC of small molecules, a practical approach. (Lim, C. K., Ed.). IRL Press, Oxford and Washington D.C., USA, 13-28.

LEE, H. J. and TiTuS, J. S. (1992). Nitrogen accumulation and nitrate reductase activity in MM.106 apple trees as affected by nitrate supply. Journal of Horticultural Science, 67, 273-81.

Millard, P. and Neilsen, G. H. (1989). The influence of nitrogen supply on the uptake and remobilization of stored nitrogen for the seasonal growth of apple trees. Annals of Botany, 63, 301-9.

Moing, A. and CARde, J. P. (1988). Growth, cambial activity and phloem structure in compatible and incompatible peach/plum grafts. Tree Physiology, 4, 347-59.

Moing, A., Carbonne, F. and Gaudillere, J. P. (1990). Growth and carbon partitioning in compatible and incompatible peach/plum grafts. Physiologia Plantarum, 79, 540-6.

Moing, A. and Gaudillere, J. P. (1992). Carbon and nitrogen partitioning in peach/plum grafts. Tree Physiology, 10, 81-92.

Mosse, B. (1962). Graft incompatibility in fruit trees with special reference to its underlying causes. Technical communication No. 28, Commonwealth Agricultural Bureaux, Farnham Royal, Bucks., UK.

O'KenNedy, B. T. and Titus, J.S. (1979). Isolation and mobilization of storage proteins from apple shoot bark. Physiologia Plantarum, 45, 419-24.

Poorter, H., Remkes, C. and Lambers, H. (1990). Carbon and nitrogen economy of 24 wild species differing in relative growth rate. Plant Physiology, 94, 621-7.

Stassen, P. J. C., Stindt, H. W., Strydom, D. K. and Terblanche, J. H. (1981). Seasonal changes in nitrogen fractions of young Kakamas peach trees. Agroplantae, 13, 63-72.

TABUENCA, M.C. (1962). Relaciones entre la composición química y el grado de compatibilidad en combinaciones de melocotonero y ciruelo. Anales de la Estación Experimental de Aula Dei, 7, 1-34.

TAYlor, B. K. and MaY, L. H. (1967). The nitrogen nutrition of the peach tree. II. Storage and mobilization of nitrogen in young trees. Australian Journal of Biological Sciences, 20, 389-411.

Titus, J. S. and KANG, S. M. (1982). Nitrogen metabolism, translocation and recycling in apple trees. Horticultural Reviews, 4, 204-46.

Tromp, J. and OvaA, J. C. (1973). Spring mobilization of protein nitrogen in apple bark. Physiologia Plantarum, 29, 1-5.

Tromp, J. and OvaA, J. C. (1976). Effect of time of nitrogen application on amino-nitrogen composition of roots and xylem sap of apple. Physiologia Plantarum, 37, 29-34.

Wetzel, S., Demmers, C. and Greenwood, J. S. (1989). Seasonally fluctuating bark proteins are a potential form of nitrogen storage in three temperate hardwoods. Planta, 178, 275-81. 